\title{
THE FEATURES OF INTERACTION RHIZOBIUM GALEGAE WITH GALEGA ORIENTALIS
}

\author{
Yu. O. Vorobei, V. S. Vorobei, A. V. Piroh \\ Institute of Agricultural Microbiology and Agroindustrial Manufacture, NAAS, \\ City of Chernihiv
}

The strain of Rhizobium galegae K- 3 - active symbiote of Galega orientalis has been received by means of selection. Positive influence of this strain on formation and functioning of symbiosis during the first and second years of cultivation of Galega orientalis plants is shown. $R$. galegae $K$ - 3 promotes to formation of generous amount of indeterminate nodules on the roots, increase of activity of symbiotic nitrogen fixation and increase in the yield of Galega orientalis.

Key words: Rhizobium galegae, Galega orientalis, legume-rhizobial symbiosis

Today, significant attention is paid to the introduction of different legumes with economically valuable signs into the culture. According to the literature, new macrocultural species, which are similar to their wild relatives by physiological properties, have a high symbiotic potential [1]. Use of Galega orientalis in agriculture is due to its high winter resistance and productivity, intensive growth and longevity, early spring regrowth of tops, the ability for utilization at the same place for 10-12 years, as well as high quality of feed obtained without the use of nitrogen fertilizers - due to the symbiotic nitrogen fixation [2; 3]. Increased ability of Galega orientalis to fix atmospheric nitrogen, prevalence of symbiotrophic nutrition over autotrophic, high sensitivity to inoculation with specific strains of rhizobia have a positive impact of bacterization on productivity of culture and quality of raw materials.

Cultivation of Galega orientalis on soils where no active strains of specific rhizobia are present requires the use of biopreparation for pre-seeding bacterization, which in turn stipulates extensive research of features of legume-rhizobial symbiosis formation.

The aim of this paper was to study features of relationships of Rhizobium galegae with Galega orientalis plants.

Materials and methods. Study of the inoculation efficiency of Galega orientalis (variety Kavkazskyi branets) by the strains of $R$. galegae was conducted under the conditions of field experiment on sodpodzolic sandy loam soil ( $\mathrm{pH}$ - 6.47; humus content - 0.8-1.1\%; easily-hydrolysed nitrogen (by Tiuryn and Kononova) - 56.0$57.0 \mathrm{mg} ; \mathrm{P}_{2} \mathrm{O} 5$ - 160.0-170.0 $\mathrm{mg}$ and $\mathrm{K}_{2} \mathrm{O}$ (by Kirsanov) - 100-110 mg per $1 \mathrm{~kg}$ of soil). Planting was carried out by the widerow method, row spacing $-40 \mathrm{~cm}$. Seeding norm - $10 \mathrm{~kg} / \mathrm{ha}$. Before seeding, seeds were scarified and inoculated with the strains of rhizobia at a rate of 200-300 thous. cells/seed. Standard strain of $R$. galegae 0703 obtained from the collection of beneficial soil microorganisms [4] and strain $R$. galegae $\mathrm{K}-3$, isolated from nodules of Galega orientalis were used for bacterization.

Nodules were sampled from the roots of Galega orientalis for cytological tests, wash them out from the soil residues and fixed by FAA ( $16 \%$ formalin - 1 portion, acetic acid (concentrated) - 1 portion; $96 \%$ alcohol - 5 portions). Glutaric aldehyde was also used for fixing nodules. Fixative was washed out in $80 \%$ alcohol solution. Fixed material was dehydrated by four-fold washing in alcohol (from $96 \%$ to $100 \%$ ), keep in the solution containing of alcohol and toluene with gradual alcohol replacement by toluene. Then toluene was replaced by paraffin. Longitudinal microtome slices were obtained from the fixed material by paraffin blocks method [5]. A part of obtained slices were left 
unstained, the rest of the slices were stained by haematoxylin.

For electron-microscopic examination, nodules of plants inoculated by $R$. galegae K-3 were separated, cut into the layers of $1 \mathrm{~mm}$ thickness, fixed with $6 \%$ glutaric aldehyde solution and $1 \% \mathrm{OsO}_{4}$ [6]. Dehydration of fixed material as performed by 50, 70, 76 and $100 \%$ alcohols and poured in Epone-812. Ultrathin slices were obtained on ultramicrotom BS 490A, stained with uranyl acetate, examined under electronic microscope BS-540 “Tesla”.

In the main phase of plant development of the first and second years of cultivation, number of nodules on the roots of plants and activity of symbiotic nitrogen fixation measured by acetylene method, were determined [7]. Roots were sampled from soil-plant monoliths of 22x22x27 cm, carefully separating from the soil, washed and placed them in bottles where acetylene was injected. Incubation time was 1 hour. Amount of reduced ethylene was measured on a gas chromatograph Chrom-4. Then the roots were removed from the bottles, and number of nodules was counted.

Mowing of plants was on the first and second year of vegetation of Galega orientalis in the flowering stage, with further measurement of their air dry tops.

Statistical processing of experimental data was carried out by B. O. Dospiekhov [8] using computer program Statistica 6.0.

Therefore, selected active strain Rhizobium galegae K-3 forms an effective nitrogen-fixing symbiosis with plants of Galega orientalis and promotes formation of the significant number of nodules with distinct histological zoning on the roots that is typical for non-determinated type of nodules. It has been established that symbiotic apparatus of Galega orientalis, formed during the first year, after wintering retains its structure and functional activity. During the second year of plants cultivation, increase in the number of nodules on the roots of plants and a significant increase in the level of symbiotic nitrogen fixation is observed since the beginning of regrowth of the tops. Mowing of Galega orientalis does not affect intensity of nodule formation, but significantly reduces the activity of symbiotic nitrogen fixation. Strain Rhizobium galegae K-3 improves productivity of Galega orientalis by $20 \%$, in total of two years of cultivation compared with control. 